\title{
Bacterial abundance and production during the unique spring phytoplankton bloom in the central Yellow Sea
}

\author{
Jung-Ho Hyun ${ }^{1, *}$, Kyeong-Hong Kim ${ }^{2}$ \\ ${ }^{1}$ Marine Microbiology Laboratory and ${ }^{2}$ Deep-Sea Resources Research Center, Korea Ocean Research and \\ Development Institute, Ansan, PO Box 29, Seoul 425-600, Korea
}

\begin{abstract}
To elucidate the factors responsible for the resulting bacterial properties during the spring phytoplankton bloom in the central Yellow Sea, we investigated bacterial abundance and production together with physico-chemical and biological parameters. In spring, the central Yellow Sea is characterized by the horizontal intrusion of high-temperature and high-salinity Yellow Sea Warm Current (YSWC), which forms a thermohaline front between the central Yellow Sea and cold coastal waters, and by the vertical mixing of high-nutrient Yellow Sea Cold Water (YSCW) over the previous winter. The combination of high nutrient conditions with weak vertical density gradients because of increased irradiance, which increases the residence time of phytoplankton within the euphotic layer, seems to trigger the spring phytoplankton bloom. Enhanced bacterial biomass, production, and turnover rates were observed in the bloom area. Bacterial variables were significantly correlated with chl a concentration, but not with temperature. These results indicated that resource supply from phytoplankton primarily stimulated bacterial growth. Despite the enhanced bacterial growth in the bloom area, abundant heterotrophic nanoflagellates and their grazing on bacteria were responsible for the relatively smaller increase in bacterial biomass in the bloom area. Higher bacterial growth but smaller increases in bacterial biomass indicated that bacterial growth and biomass are independently controlled during the spring bloom in the central Yellow Sea, in which bacterial growth is primarily stimulated by organic material produced from the phytoplankton bloom, but the enhanced biomass is more tightly controlled by grazing.
\end{abstract}

KEY WORDS: Bacterioplankton · Yellow Sea · Spring bloom · Yellow Sea Cold Water · YSCW · Yellow Sea Warm Current · YSWC

\section{INTRODUCTION}

Bacterioplankton play a significant role as both remineralizers of organic carbon and trophic intermediaries in aquatic ecosystems (Pomeroy 1974, Azam et al. 1983). Thus, elucidating the major determinants of bacterial abundance and production in various aquatic environments is a significant ecological issue (Ducklow \& Carlson 1992). Several physico-chemical and biological parameters have been proposed as factors controlling bacterial biomass and growth. Dissolved organic carbon may be a major resource, limiting bacterial growth in many cases (Billen et al. 1990, Kirch- man 1990). The concept of resources limiting bacterial growth has been supported by positive correlations between phytoplankton and bacterial parameters (Bird \& Kalff 1984, Cole et al. 1988, Ducklow 1999). Temperature has also been suggested as a key factor controlling bacterial growth in temperate estuarine and cold coastal waters (Pomeroy \& Deibel 1986, White et al. 1991, Shiah \& Ducklow 1994). In various aquatic environments, protozoan grazing (Rassoulzadegan \& Sheldon 1986, Sherr et al. 1992) and viral lysis (Proctor \& Fuhrman 1992, Suttle 1994) have been related to the variations in bacterial abundance. Meanwhile, other research concluded that the physical stability of the 
water column, which largely controls the trophic conditions, determines bacterial distribution and production and their quantitative role in microbial food-web processes (Cushing 1989, Kiørboe et al. 1990, Cho et al. 2001, Shiah et al. 2001). In combination, these results suggest that the factors controlling bacterial populations are system-dependent. Therefore, to understand the factors influencing bacterial populations in a given environment, it is important to characterize both the water column structure and the trophic state of the water mass in space and time (Sanders et al. 1992, Dufour \& Torréton 1996).

The Yellow Sea is a semi-enclosed continental shelf environment with complex physico-chemical characteristics (KORDI 1998). It is often divided into 4 major water masses: (1) the high temperature, high salinity Yellow Sea Warm Current (YSWC); (2) the high nutrient Yellow Sea Cold Water (YSCW); (3) the low temperature, low salinity Coastal Current Water (CCW); and (4) the low salinity Chiangjiang River Diluted Water (CRDW) (Lie 1984). These water masses interact differently depending on the season (Lie 1986, Kim et al. 1991, Lie et al. 2000). During the Korea-China joint cruise, which was designed for the study of water circulation and material flux in the Yellow Sea, we observed unusually high chl a concentrations and enhanced bacterial biomass and production in the central Yellow Sea. Because spring in the Yellow Sea is characterized by the mixing of the aforementioned water masses, all of which have different temperatures and nutrient levels, an interesting ecological question arises as to the factors responsible for both the phytoplankton bloom and the bacterial abundance, production and removal.

The objective of this study was to determine the physico-chemical and biological parameters associated with the bacterial populations in the central Yellow Sea during the spring phytoplankton bloom. First, we report the unique mechanism of the spring bloom in the central Yellow Sea, which differs fundamentally from the mechanism previously reported for the phytoplankton bloom associated with the tidal front in the Yellow Sea. Second, we discuss the relative significance of resources in the enhanced bacterial abundance and production in the bloom area. The intense grazing activity that controls bacterial abundance during the spring phytoplankton bloom is also discussed.

\section{MATERIALS AND METHODS}

Sampling. Investigations on the physico-chemical and microbiological parameters were performed from 6 to 16 April, 1996, at stations along 3 survey lines (Transects B, D and F) and at 3 temporal stations along
1 survey line (Transect P) in the mid-eastern region of the Yellow Sea (Fig. 1). Water temperature and salinity were measured using a CTD meter (SBE 911 Plus, Seabird Electronics). Seawater samples for chemical and microbiological analyses were collected in acidwashed $(10 \% \mathrm{HCl})$ Niskin bottles attached to a rosette sampler.

Nitrate and chl a. Water samples for nitrate analyses were collected using acid $(10 \% \mathrm{HCl})$-washed polyethylene bottles, and stored at $-20^{\circ} \mathrm{C}$ until they were processed in the lab. Nitrate concentrations were measured according to Parsons et al. (1984). Chlorophyll a $(\mathrm{chl}$ a) concentrations were measured using a spectrophotometer after acetone extraction (Parsons et al. 1984). In situ chl a fluorescence was also measured, using an in situ fluorometer (Seatech) to obtain vertically continuous distributions of chl $a$. The chl a concentration in the whole water column was then calculated from the linear relationship between in situ fluorescence (flu) and spectrophotometrically obtained measurements (i.e. chl $a=0.953 \times$ flu $+0.554 ; r^{2}=$ $0.965, \mathrm{n}=71$ ). Phytoplankton carbon biomass was estimated using a C:chl a ratio of 60 within $30 \mathrm{~m}$ depth and a ratio of 40 between 30 and $60 \mathrm{~m}$ depth of the water column (Caron et al. 1995).

Bacterial abundance and production. The abundance of bacteria was measured according to the method of Porter \& Feig (1980). Samples for bacterial abundance were preserved with glutaraldehyde (final conc. $1 \%$ ), and stored in a freezer at $-20^{\circ} \mathrm{C}$ until bac-

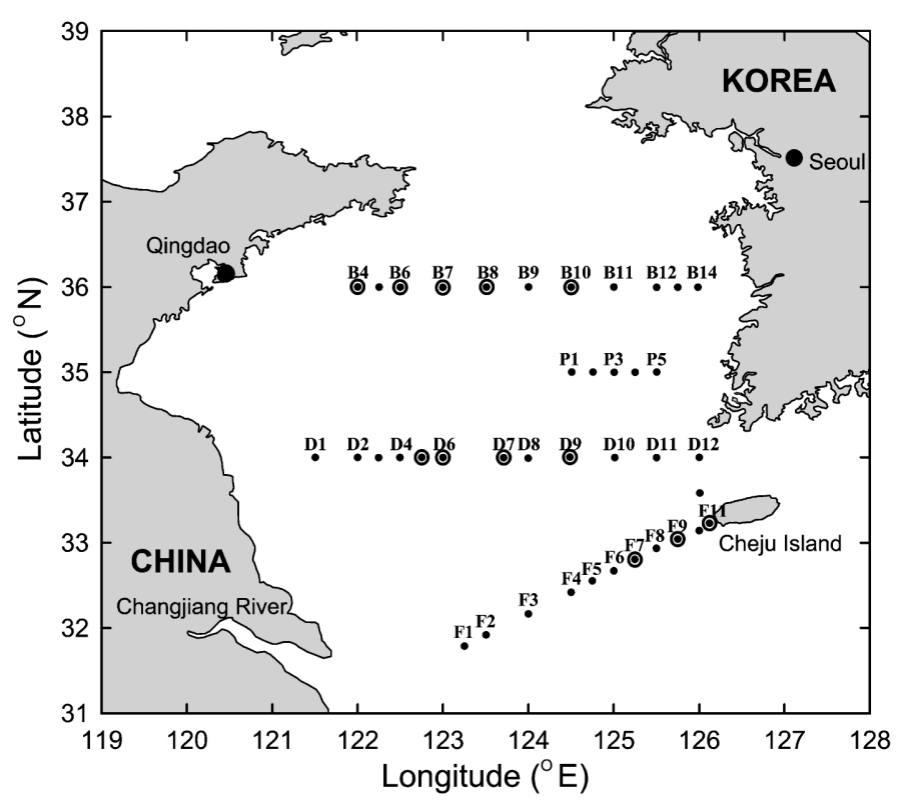

Fig. 1. Map of study area showing stations where physico-chemical parameters (temperature, salinity, nitrate and chl a) were measured or analyzed (small circles), and stations where bacterial abundance and production were measured (double circles) 
terial abundance was enumerated in the laboratory. Since there is often a substantial decrease in bacterial cell numbers when stored for long periods at $4^{\circ} \mathrm{C}$ (Turley \& Hughes 1992, Kepner \& Pratt 1994), we froze each sample immediately after adding the fixatives (cf. Smith 1998, Choi et al. 1999). Previously, we found that there was no significant reduction in bacterial cell numbers in samples that were frozen and thawed once (data not shown). Water samples were thawed and stained with DAPI, filtered through Nuclepore filters $(0.2 \mu \mathrm{m}$ pore size, black), and mounted on slides with immersion oil (Cargille type A). Bacteria were enumerated using an epifluorescence microscope (Nikon type 104) equipped with a mercury lamp (HB-10101 AF), a UV excitation filter, and a BA 420 barrier filter. Bacterial carbon biomass was estimated from bacterial cell numbers using a conversion factor of $15 \mathrm{fg} \mathrm{C} \mathrm{cell}^{-1}$ (Caron et al. 1995). Bacterial production was estimated from the rate of ${ }^{3} \mathrm{H}$-thymidine $\left({ }^{3} \mathrm{H}-\mathrm{TdR}\right)$ incorporation (Fuhrman \& Azam 1980, 1982). Briefly, duplicated $20 \mathrm{ml}$ seawater samples were incubated with ${ }^{3} \mathrm{H}$-TdR (final conc. $5 \mathrm{nM}$ thymidine, New England Nuclear, NET 027X) at in situ surface water temperature for 30 min in disposable plastic centrifuge tubes. Samples were poured into a $50 \%$ ice-cold trichloroacetic acid (TCA) solution (final conc. 5\%), and TCA-insoluble macromolecules were extracted in an ice-bath for $15 \mathrm{~min}$. Samples were then collected by vacuum filtration on $0.2 \mu \mathrm{m}$ cellulose nitrate membrane filters (MFS), and rinsed 3 times with ice-cold $80 \%$ ethanol. Filters were placed in scintillation vials with $10 \mathrm{ml}$ of scintillation cocktail (Lumagel Safe, Lumac-LSC), and the radioactivity of the TCA-insoluble macromolecules was determined using a liquid scintillation counter (LKB, RackBeta II). A conversion factor of $1.18 \times$ $10^{18}$ cells mol $^{-1}$ was used to convert the TdR measurements into bacterial cell production (Rieman et al. 1987).

Heterotrophic nanoflagellate (HNF) abundance and grazing. The water samples used to enumerate HNF were preserved with glutaraldehyde (final conc. $0.5 \%$ ), and kept in a refrigerator until processing. Ten to $15 \mathrm{ml}$ of seawater were stained with DAPI (final conc. $1 \mu \mathrm{g} \mathrm{ml}^{-1}$ ), and filtered through Nuclepore filters ( $0.8 \mu \mathrm{m}$ pore size, black) under a vacuum of less than $100 \mathrm{~mm} \mathrm{Hg}$ (Caron 1983). HNF cells were enumerated at $1000 \times$ magnification using an epifluorescence microscope (Nikon type 104). Approximately 100 microscopic fields were examined to enumerate HNF. To examine the grazing intensity of HNF on bacteria in the bloom area, a time-course experiment was performed at depths of 10 and $25 \mathrm{~m}$ at Stn D7. Seawater samples were collected using 41 Cubitainers (Hedwin), and incubated at in situ surface water temperature. Subsamples for enumerating bacteria and HNF were collected over time. If HNF grazing were intensive, we would expect to observe a substantial grazing impact during a short incubation. Similarly, we used untreated seawater samples (i.e. no dilution or filtration) to observe direct short-term fluctuations (without lag phase) in bacterial and HNF abundance in bloom conditions (cf. Ducklow et al. 1992).

Data analysis. Area-based chl a concentrations, bacterial biomass and production, and HNF abundance were obtained from the integration of volume-based values at a depth down to the surface mixed layer, as determined from vertical profiles of either density or chl a concentration. The mean bacterial biomass turnover rate was calculated by dividing depth-integrated bacterial production by the integrated bacterial biomass. Spearman's rank correlation coefficients were calculated using SPSS (Version 8.0) to evaluate the relationships between bacterial properties, chl $a$, and temperature for both bloom and pooled (i.e. bloom plus non-bloom) conditions.

\section{RESULTS}

\section{Environmental parameters}

The intrusion of the YSWC that branched from the Cheju Warm Current (CWC) was identified by its tongue-shaped isotherm $\left(9^{\circ} \mathrm{C}\right)$ and isohaline $(33.4 \mathrm{psu})$ (Fig. 2A,B). The intrusion of the YSWC into the central Yellow Sea was also clear in the vertical temperature (T) and salinity (S) gradient from Transect $\mathrm{F}$ to the central Yellow Sea along Stns D9, D7, and B8 (Fig. 3). The YSWC was characterized by high water temperature (average $12.49^{\circ} \mathrm{C}$ ) and high salinity (average $34.41 \mathrm{psu}$ ) (Table 1). Low temperature (average $7.15^{\circ} \mathrm{C}$ ) and low salinity (average $32.54 \mathrm{psu}$ ) were observed in the CCW that appeared along the shallow coastal areas of Korea and China. The central Yellow Sea was characterized by strong thermohaline fronts at Stns D5, B6, and D9 along the boundary of the CCW and the YSWC. Vertical gradients in water temperature, salinity, and density were observed in both coastal waters and the central Yellow Sea (Fig. 3). A weak density gradient is associated with increased irradiance, and seems to increase the residence time of phytoplankton in the euphotic layer. Surface water nitrate concentrations were high in areas receiving freshwater runoff; that is, the CRDW (Stns F1 and F2) and along the southwest coast of Korea (Stns D11 and 12) (Fig. 2C). However, the nitrate concentrations below the euphotic zone of the central Yellow Sea were higher than those of the $\mathrm{CCW}$ and YSWC (Fig. 4) as a result of nutrient accumulation in the YSCW during the previous summer and fall (MOST 1998). Despite the large nitrate supply resulting from winter vertical mixing, low nitrate con- 

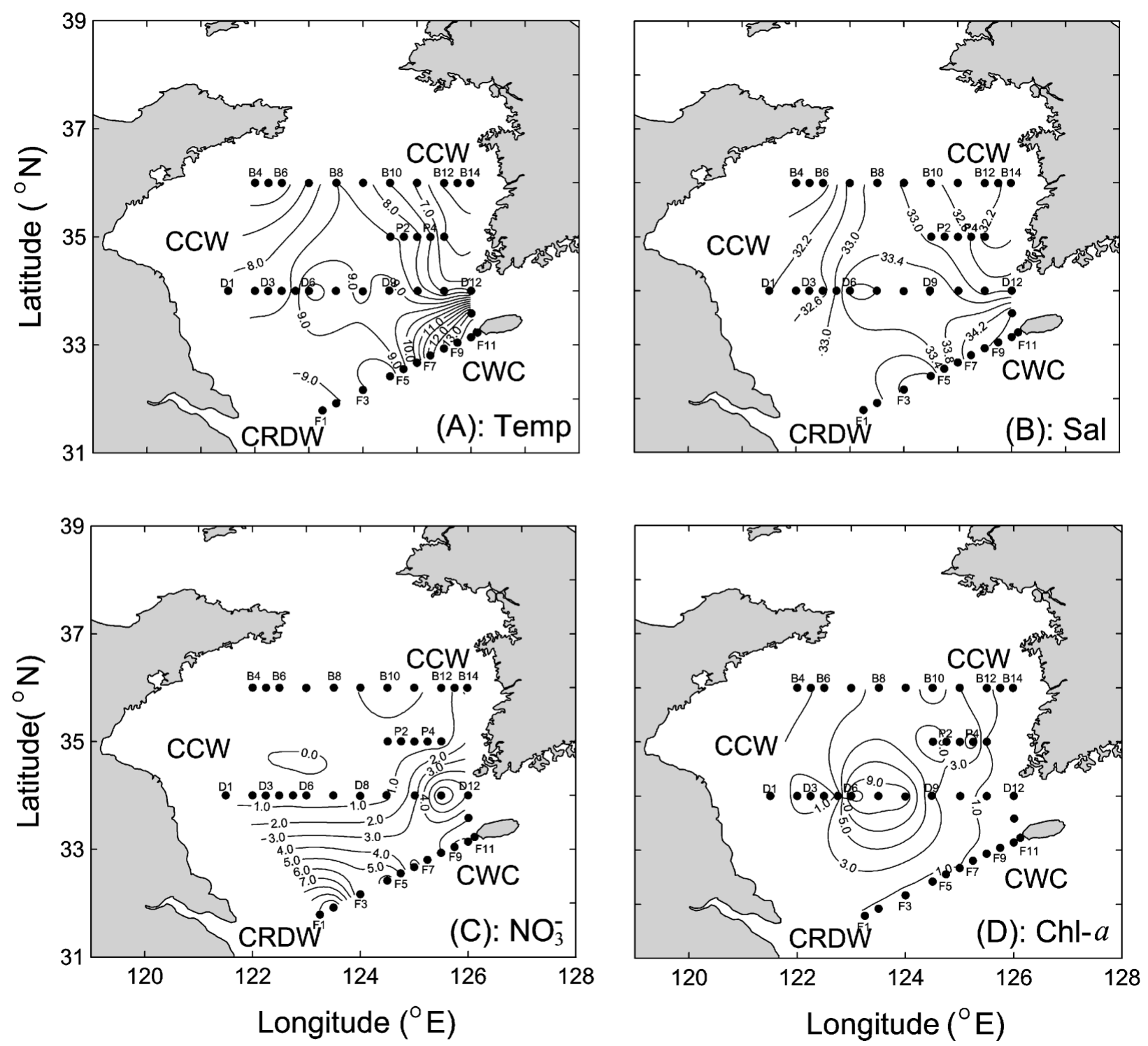

Fig. 2. Horizontal distributions of temperature, salinity, nitrate and chl a concentrations. The Yellow Sea Warm Current (YSWC) and Yellow Sea Cold Water (YSCW) were mixed within the tongue shapes in both the temperature and salinity contour. CWC: Cheju Warm Current; CRDW: Chiangjiang River Diluted Water; CCW: Coastal Current Water

centrations in the surface waters of the central Yellow Sea are due to the phytoplankton bloom (Figs. 2D \& 4).

\section{Bacterial abundance and production}

Bacterial cell numbers in the whole water column ranged from $1.38 \times 10^{5}$ to $8.95 \times 10^{5} \mathrm{cells} \mathrm{ml}^{-1}$ (average $3.16 \times 10^{5}$ ) (Fig. 5). High bacterial abundance was observed in the central Yellow Sea, where the spring phytoplankton bloom occurs (Table 1). Bacterial production varied from 0.03 to $41.35 \mathrm{pM} \mathrm{TdR} \mathrm{h}^{-1}$ (average 6.45) (Fig. 6), and higher bacterial production (up to $23.5 \mathrm{pM} \mathrm{TdR} \mathrm{h}^{-1}$ ) was also observed in the bloom area. Low bacterial abundance and production occurred in the coastal areas influenced by the cold CCW (Stns B4, B6, D4 and D5), and in areas affected by the YSWC with its high T-S but low chl a concentration (Stns D9, F7, F9 and F11). The results indicate that the springtime distributions of bacterial abundance and production in the central Yellow Sea are closely related to the distribution of chl a.

\section{Heterotrophic nanoflagellates}

Depth-integrated HNF abundance ranged from $5.3 \times 10^{9}$ to $17.9 \times 10^{9}$ cells $\mathrm{m}^{-2}$ (Table 1 ). HNF abundance was highest in the central Yellow Sea, where high bacterial abundance and production were 
Fig. 3. Vertical distributions of temperature $(\mathrm{T})$, salinity (S) and density (D) at different stations
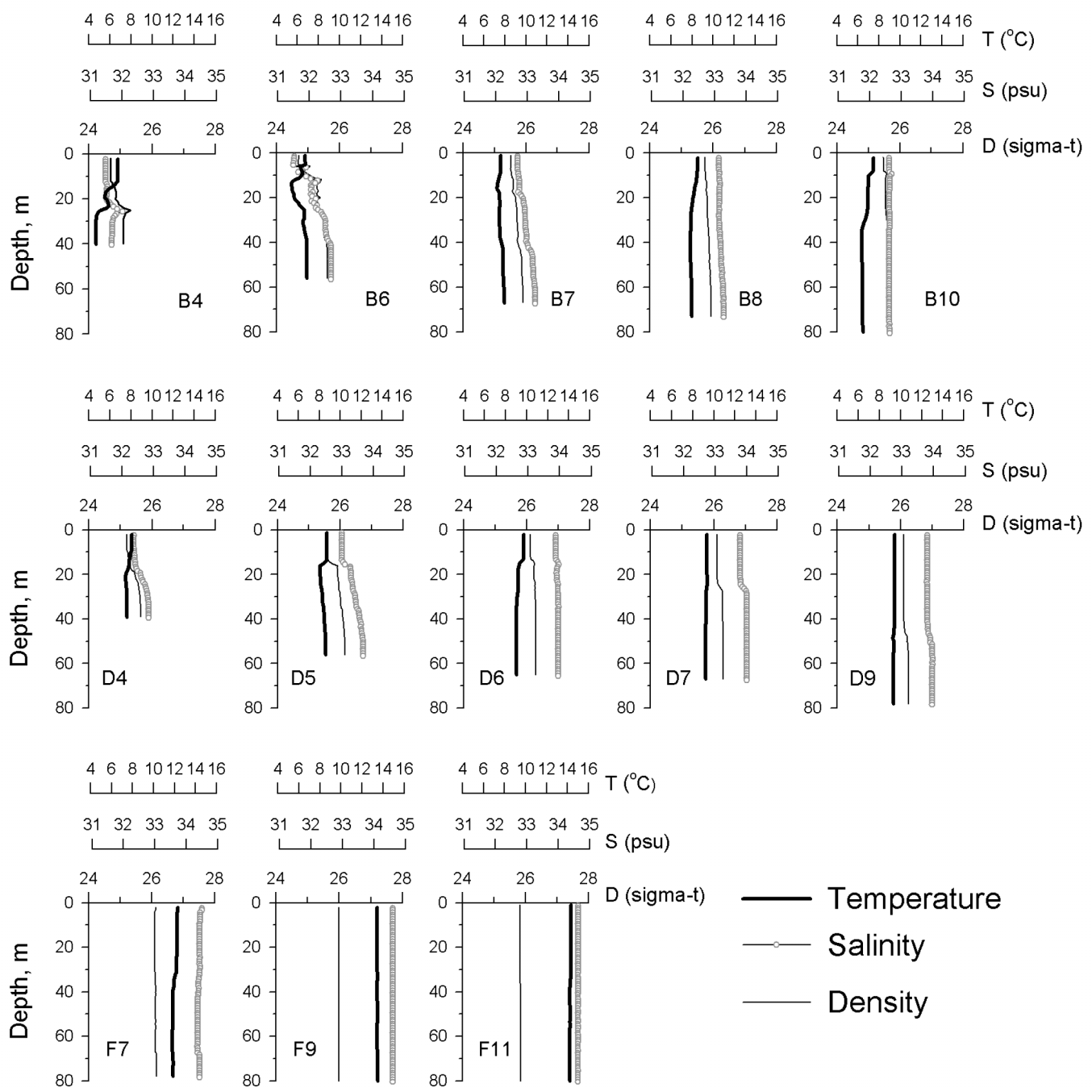

Table 1. Depth integrated phytoplankton carbon biomass (chl-C), bacterial carbon biomass (BCB), bacterial production (BP) based on TdR incorporation and carbon production, abundance of heterotrophic nanoflagellates (HNF), the ratio of BCB to chl-C and mean biomass turnover rate (Bact-TR) with different water regimes during spring phytoplankton bloom in the Yellow Sea. Depth integration in Transects B and D was performed based on the vertical gradient of density (Fig. 3) and chl a (Fig. 4), while depth integration in the $\mathrm{F}$ transect was performed down to euphotic depth $(30 \mathrm{~m})$ because no vertical gradient in density or chl a was observed. CCW: coastal current water; Central YS: mixture of Yellow Sea Warm Current and Yellow Sea Cold Water; CWC: Cheju Warm Current

\begin{tabular}{|c|c|c|c|c|c|c|c|c|c|}
\hline Water regime & Stn & $\begin{array}{c}\text { Integration } \\
\text { depth (m) }\end{array}$ & $\begin{array}{c}\text { chl-C } \\
\left(\mathrm{mg} \mathrm{C} \mathrm{m}^{-2}\right)\end{array}$ & $\begin{array}{c}\mathrm{BCB} \\
\left(\mathrm{mg} \mathrm{C} \mathrm{m}^{-2}\right)\end{array}$ & 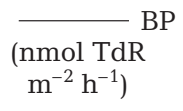 & $\begin{array}{l}(\mathrm{mgC} \\
\left.\mathrm{m}^{-2} \mathrm{~d}^{-1}\right)\end{array}$ & $\begin{array}{c}\text { HNF } \\
\left(\times 10^{9}\right. \\
\left.\text { cells m }{ }^{-2}\right)\end{array}$ & $\begin{array}{c}\text { BCB: } \\
\text { chl-C } \\
(\%)\end{array}$ & $\begin{array}{c}\text { Bact-TR } \\
\left(\mathrm{d}^{-1}\right)\end{array}$ \\
\hline $\mathrm{CCW}$ & B4 & 25 & 676.4 & 90.7 & 90.2 & 36.4 & 5.3 & 13.41 & 0.40 \\
\hline $\mathrm{CCW}$ & D4 & 20 & 598.4 & 107.6 & 151.6 & 61.1 & - & 17.98 & 0.57 \\
\hline CCW (edge) & D5 & 20 & 1238.3 & 100.6 & 244.4 & 98.6 & 5.8 & 8.12 & 0.98 \\
\hline Central YS (front) & B6 & 25 & 2049.3 & 95.6 & 129.0 & 51.9 & - & 4.67 & 0.54 \\
\hline Central YS & B7 & 30 & 4441.5 & 239.6 & 223.7 & 90.2 & 11.1 & 5.39 & 0.38 \\
\hline Central YS & B8 & 30 & 6269.7 & 219.7 & 394.2 & 158.9 & 15.2 & 3.50 & 0.72 \\
\hline Central YS & B10 & 30 & 11147.4 & 158.9 & 301.6 & 121.6 & 17.9 & 1.43 & 0.77 \\
\hline Central YS & D6 & 20 & 13107.0 & 146.8 & 651.4 & 262.6 & - & 1.12 & 1.79 \\
\hline Central YS & D7 & 30 & 16855.2 & 211.5 & 312.5 & 126.0 & 12.8 & 1.25 & 0.60 \\
\hline Central YS (front) & D9 & 50 & 8150.6 & 152.0 & 115.8 & 46.6 & - & 1.86 & 0.31 \\
\hline CWC & F7 & 30 & 1215.0 & 100.8 & 39.5 & 15.7 & - & 8.30 & 0.16 \\
\hline CWC & F9 & 30 & 1659.0 & 104.0 & 61.2 & 24.3 & - & 6.27 & 0.23 \\
\hline \multirow[t]{2}{*}{ CWC } & F11 & 30 & 736.8 & 125.5 & 175.2 & 69.4 & - & 17.03 & 0.55 \\
\hline & & Mean: & 5241.9 & 142.6 & 222.3 & 89.5 & 11.4 & 6.95 & 0.62 \\
\hline
\end{tabular}




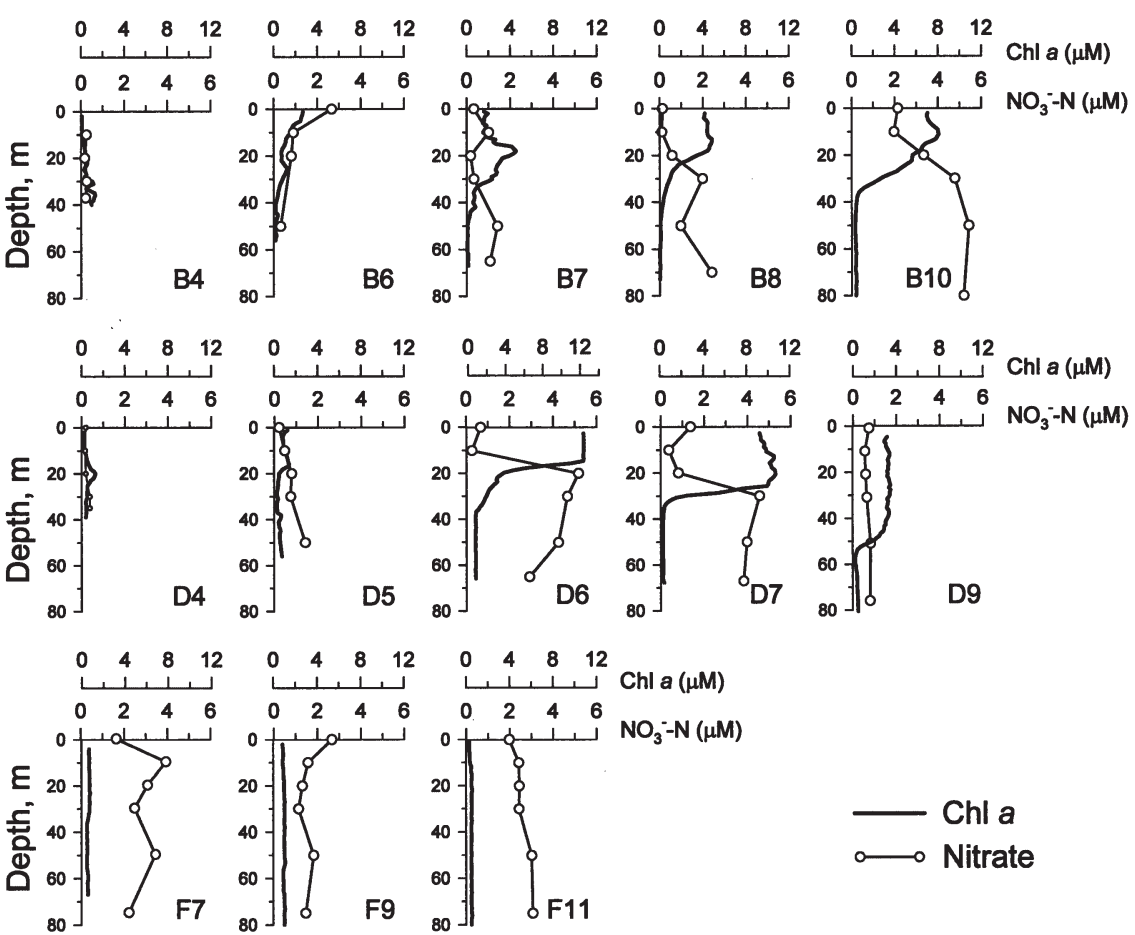

Fig. 4. Vertical distributions of $\mathrm{chl} a$ and nitrate $\left(\mathrm{NO}_{3}{ }^{-}-\mathrm{N}\right)$ concentrations at different stations bacterial cell (Sherr et al. 1992). Mean biomass turnover rates of bacteria in the bloom area were generally higher (average $0.73 \mathrm{~d}^{-1}$ ) than those in the CCW (average $0.65 \mathrm{~d}^{-1}$ ) and in the CWC (average $0.31 \mathrm{~d}^{-1}$ ). The high bacterial production in the central Yellow Sea is owing to the high turnover rate of bacterial populations. Despite the high bacterial production, we observed little increase in bacterial biomass, which we attribute to protozoan grazing on the actively growing bacterial biomass (Fig. 7).

\section{DISCUSSION}

\section{Spring bloom in the central Yellow Sea}

Our results are the first to report, to our knowledge, the spring phytoplankton bloom and subsequent high bacterial abundance and production associated with large-scale mixing of water masses in the central Yellow Sea. Several studies have reported on the phytoplankton of the coastal tidal front of the Yellow Sea (Cho et al. 1983, Choi et al. 1995). The Yellow Sea coastal waters are physically well mixed with strong tidal currents ( 1 to $5 \mathrm{~m} \mathrm{~s}^{-1}$ ) and large tidal ranges (3 to $8 \mathrm{~m}$ ) (OHA 1978). A tidal front in the Yellow Sea occurs observed. To test the impact of grazing on bacterial abundance in the bloom area, time-course experiments were performed at 2 depths (10 and $25 \mathrm{~m}$ ) at Stn D7 (Fig. 7). HNF started to control bacterial abundance at concentrations of $6.5 \times 10^{8}$ and $5.4 \times 10^{8}$ bacterial cells $\mathrm{l}^{-1}$ at 10 and $25 \mathrm{~m}$, respectively. However, the increase in bacterial cell numbers resumed when HNF growth was retarded at $\mathrm{HNF}$ abundances of $9.0 \times 10^{5} \mathrm{HNF}$ cells $\mathrm{l}^{-1}$ at both depths. These results indicate that HNF tightly controlled bacterial abundance in the bloom area.

\section{Biomass structure and turnover}

Depth-integrated bacterial carbon biomass (BCB) was 1.12 to $17.98 \%$ (average $6.95 \%$ ) of phytoplankton carbon biomass (chl-C) (Table 1). An extremely low BCB:chl-C ratio was observed in the bloom area of the central Yellow Sea, with a range of 1.12 to $5.39 \%$. A low BCB:chl-C ratio in the bloom area seems to result from either the time lag between phytoplankton and bacterial growth (Billen \& Fontigny 1987) or protozoan grazing on the actively growing

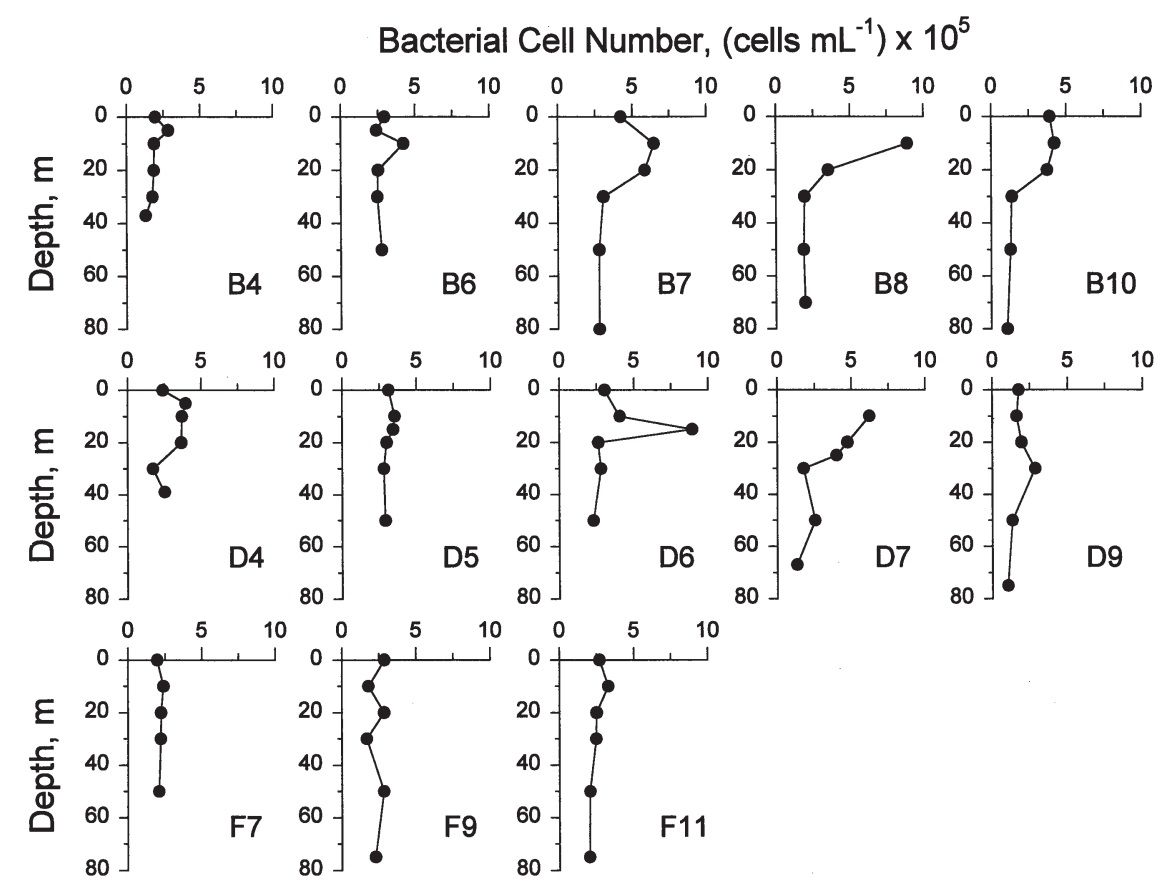

Fig. 5. Vertical distributions of bacterial cell numbers at different stations 
Thymidine Incorporation Rate, $\mathrm{pM} \mathrm{hr}^{-1}$
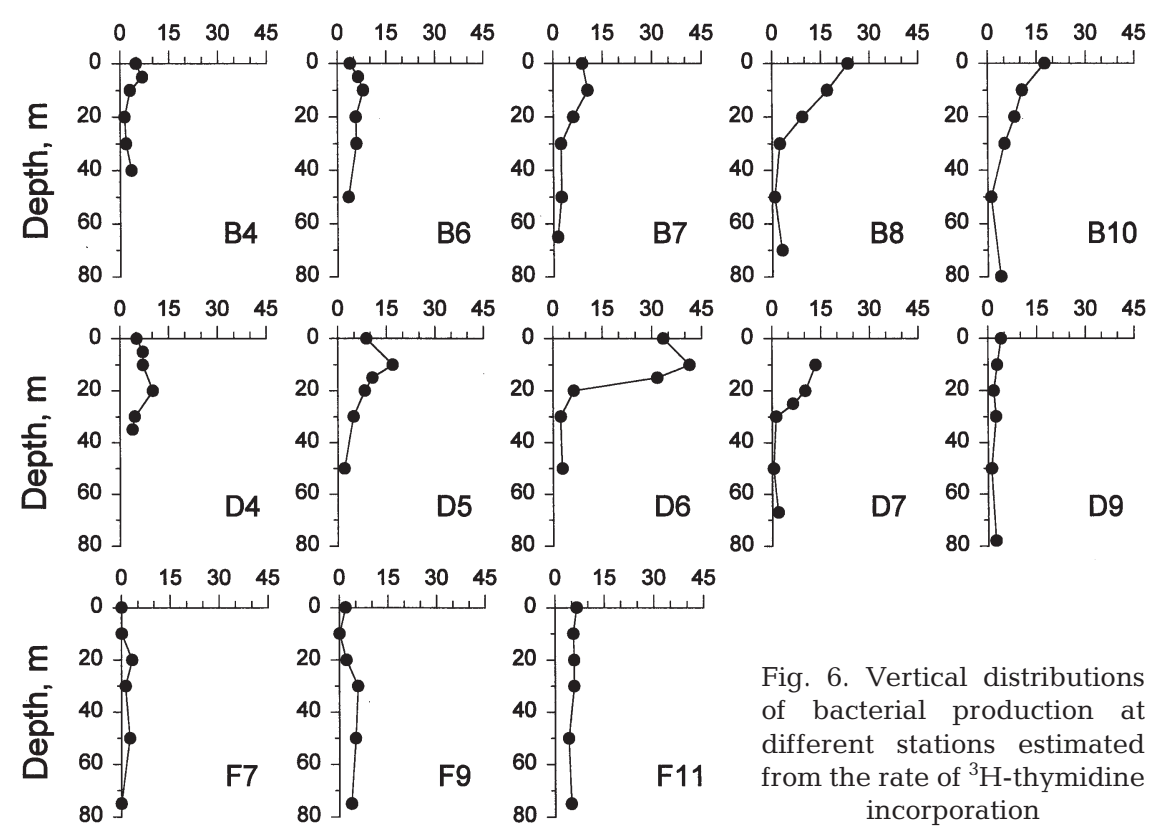

F7

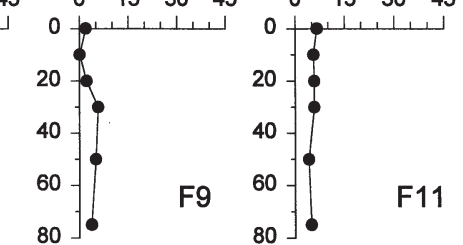

F11
Fig. 6. Vertical distributions of bacterial production at different stations estimated from the rate of ${ }^{3} \mathrm{H}$-thymidine incorporation

the central Yellow Sea. Actually, the nitrate concentration in the bottom layer of the central Yellow Sea was higher than that of coastal waters (Fig. 4). Moreover, the weak vertical density gradient (Fig. 3), which forms as a result of the increased irradiance in spring, results in a longer residence time for phytoplankton in the euphotic zone, and triggers the phytoplankton bloom (Sverdrup 1953). The direct impact of the YSWC on the phytoplankton bloom in the central Yellow Sea is not clear at this point. However, there was a decreasing gradient of T-S nitrate together with an increasing chl a concentration at the stations along Transect F and Stns D9, D7 and D6 (Figs. 3 \& 4), suggesting that the phytoplankton bloom in the central Yellow Sea is stimulated, to some extent, by the intrusion of the high T-S YSWC.

at the boundary of the turbid coastal waters and the stratified offshore waters during late spring and fall (Seung et al. 1990, Choi 1991, Choi et al. 1995). Generally, in the frontal area, high phytoplankton and bacterial biomasses occur when turbid and high-nutrient coastal waters meet stratified and low-nutrient offshore waters (Pingree et al. 1975, Floodgate et al. 1981). In a study of plankton distribution around the Yellow Sea front, Cho et al. (1983) found a discontinuity in the species composition of phytoplankton and zooplankton at the boundary. Choi (1991) also reported a higher phytoplankton biomass and primary production at the frontal region than in the turbid inner coastal and stratified offshore waters. Lie (1989) described 4 strong tidal mixing zones in the Yellow Sea: the northwestern, midwestern, and southwestern coast of Korea, and the mideastern coast of China.

Our results indicate that the cause of the spring bloom in the central Yellow Sea and around the thermohaline front differs fundamentally from that of the enhanced phytoplankton biomass observed at the coastal tidal front. The bloom in the central Yellow Sea is associated with high nutrient conditions that are caused by the winter mixing with YSCW (Fig. 4) and weak vertical stratification (Fig. 3), which enhances the residence time of phytoplankton in the highnutrient surface water. The intrusion of the high T-S YSWC induces a strong thermohaline front that separates the warm central Yellow Sea from cold coastal waters. Therefore, the nitrate supplied from the vertical mixing of the YSCW during winter seems to be the nutrient source of the spring phytoplankton bloom in
A description of the physical properties of the water mass in the Yellow Sea is beyond the scope of this paper; they were well defined in Lie et al. $(1999,2000)$.
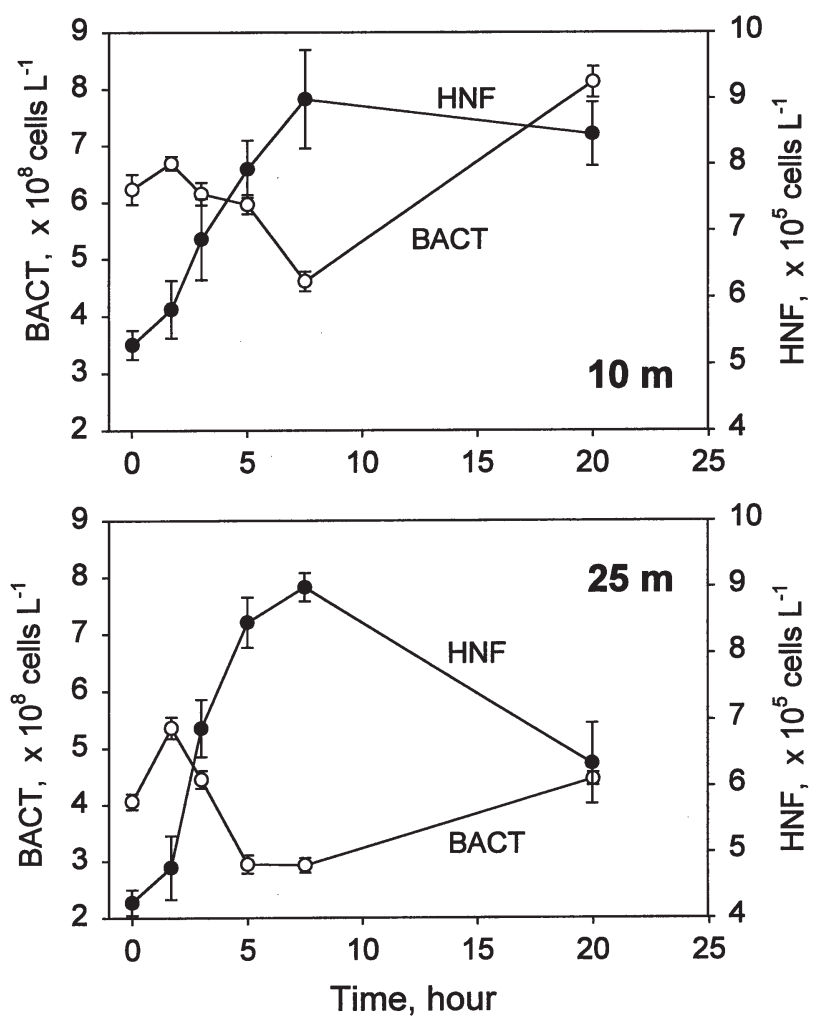

Fig. 7. Time-course experiment showing grazing impact by heterotrophic nanoflagellates (HNF) on the bacteria (BACT) at 2 water depths in the bloom area of the central Yellow Sea 
However, to elucidate the unique mechanism of the spring phytoplankton bloom in the central Yellow Sea, it is essential to understand the seasonal and spatial variation of each water mass in the Yellow Sea. Based on our results in Figs. 2 to 6 and results from the literature on the variation in water mass and chemical parameters, we suggest a scenario for the unique mechanism of the spring phytoplankton bloom in the central Yellow Sea (Fig. 8). In summer (May to October), the extension of the CRDW isolates the Yellow Sea from the CWC, which flows clockwise along the western boundary of Cheju Island (Kim et al. 1991). The saline YSWC, which originates from the CWC, does not intrude into the Yellow Sea during the summer monsoon (Park 1986, Lie et al. 1999). The Yellow Sea water column is strongly stratified, with warm, low salinity water in the surface mixed layer (20 to $30 \mathrm{~m}$ ), and cold, saline water in the bottom layer (Lie 1986). This cold, lower water mass is the YSCW, which is formed by the cold northwest wind during the previous winter (Chen et al. 1994). After the spring phytoplankton bloom, an accumulation of particulate organic matter occurs in the bottom layer, resulting in high nutrient regeneration at the bottom of the YSCW (Kim et al. 2000). In winter (November to February), strong northwest winds transport the surface waters southward, causing the bottom waters to move north. This large-scale circulation, caused by strong winds together with surface cooling, results in a vertically homogenous water mass (Chen et al. 1994, Lie et al. 2000). During this period, the intrusion of the high temperature, high salinity YSWC occurs intermittently (Hsueh 1988). The mixing allows nitrate concentrations to become vertically homogenous, and reach up to $6 \mu \mathrm{M}$ concentrations in surface waters (KORDI 1998). Despite the high nutrient supply from the bottom waters of the YSCW, chl a concentration is low $\left(<0.2 \mu \mathrm{g} \mathrm{l}^{-1}\right.$; KORDI 1998). A vertically homogenous water column may cause no accumulation of phytoplankton in the euphotic zone (see Mann \& Lazier 1991). Therefore, the low chl a seems to
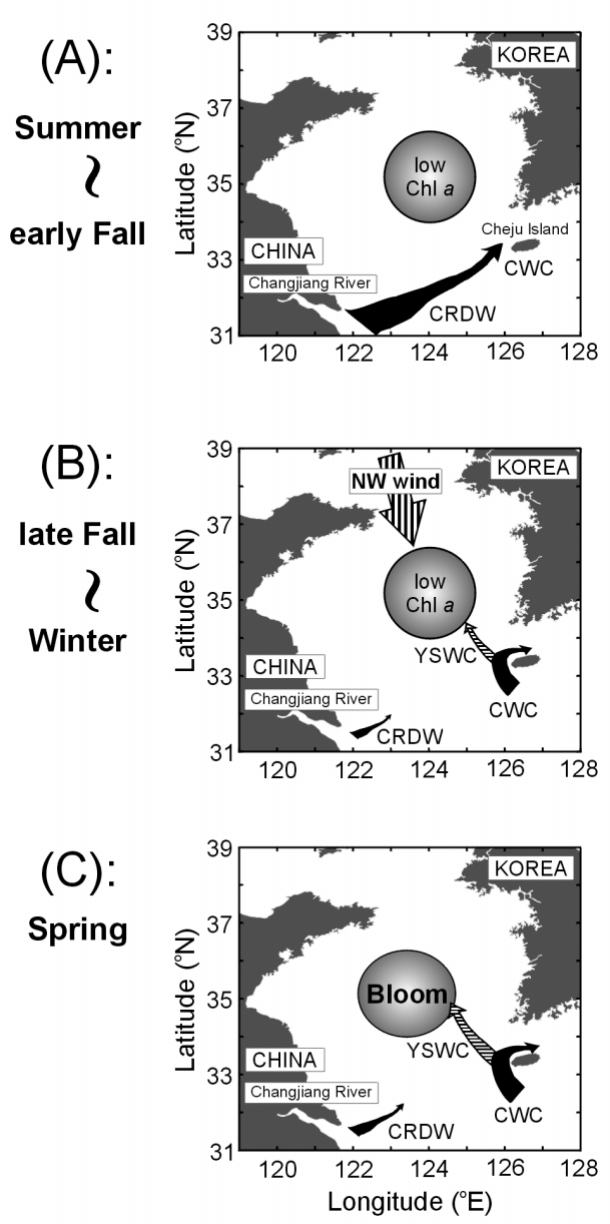

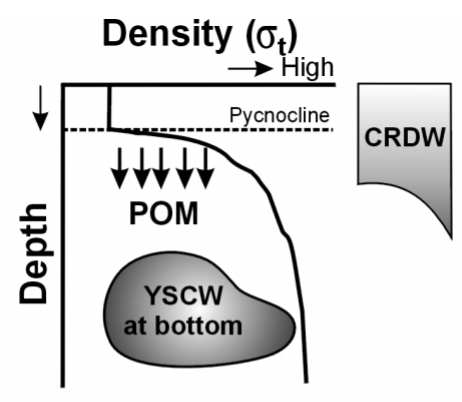
Summer :
- Horizontal extension of the CRDW
- isolation of the Yellow Sea from the CWC
- Strong summer stratification
- isolation of the YSCW from surface water
- accumulation of organic matter in the bottom layer after a spring bloom
$\rightarrow$ high nutrient accumulation in the YSCW

\section{Winter :}

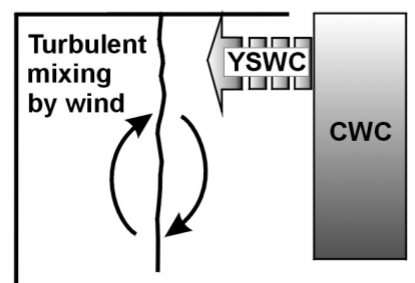

- Blowing of cold northwest wind

- vertically homogenous water column

$\rightarrow$ high nutrient conc. in surface water, but low $\mathrm{Chl}$ a due to deep mixed layer

- Intermittent intrusion of the YSWC

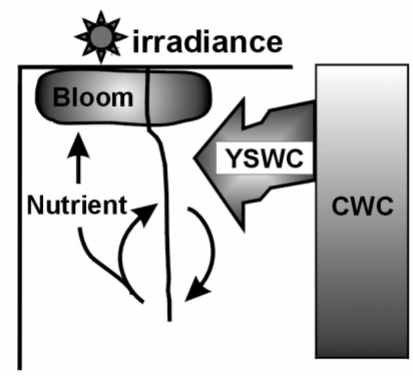

Spring :

- Frequent intrusion of the high T-S YSWC

- strong thermohaline front separating the central Yellow Sea from the cold CCW

- Enhanced irradiance

- weak vertical density gradient enhancing residence time of the phytoplankton in the high nutrient surface waters

$\rightarrow$ Spring bloom in the central Yellow Sea

Fig. 8. Seasonal circulation patterns of the major water masses and the development of the spring bloom in the central Yellow Sea. CWC: Cheju Warm Current; CRDW: Chiangjiang River Diluted Water; CCW: Coastal Current Water; YSCW: Yellow Sea Cold Water; YSWC: Yellow Sea Warm Current 
be due to the deep mixed-layer depths that are deeper than the critical depth, thus preventing phytoplankton from blooming (Sverdrup 1953). Further studies on the plankton dynamics associated with water mixing in the winter should be conducted. Finally, the water mass in spring (February to April) is characterized by more frequent intrusions of the high T-S YSWC waters from the CWC (Lie et al. 2000) (Fig. 2). Lie et al. (1999) reported that $46.6 \%$ of the total water volume has a salinity between 33 and $34 \mathrm{psu}$, the typical salinity range in the YSWC. The YSWC intrusion forms thermohaline fronts along the boundary of the high T-S YSWC and the low T-S CCW, supplies heat and salt into the area, and finally separates the central Yellow Sea from the cold and turbid coastal water environments. A weak vertical density gradient (Fig. 3) results from the increased irradiance that occurs at this time, which ultimately increases the retention time of phytoplankton in the surface mixed layer. The combination of enhanced irradiance with the effect of mixing of the YSWC and the high-nutrient YSCW seems to cause the spring phytoplankton bloom in the central Yellow Sea.

\section{Factors controlling bacterial variables}

The peaks of bacterial abundance and production coincided with the peaks in chl a concentration (Figs. 4 to 6), which indicates that bacterial variables in the central Yellow Sea were tightly coupled with phytoplankton (or bottom-up processes). However, direct coupling of bacteria with phytoplankton may be due to a common external factor affecting both bacteria and phytoplankton. Since the bloom occurred in the central Yellow Sea, where YSWC mixes with YSCW, water temperature might act as a co-variable for bacteria and phytoplankton. Therefore, the key question pertaining to bacterial populations is which factor - temperature or resource-is more important in determining the high bacterial abundance and production in the central Yellow Sea. To examine the relative significance of resources and temperature for bacteria, correlation analyses were performed between bacterial variables and chl a concentration and water temperature within the euphotic zone of the central Yellow Sea. In the bloom condition, bacterial abundance $\left(\mathrm{r}^{2}=0.237, \mathrm{p}=0.013\right)$, production $\left(\mathrm{r}^{2}=0.568 . \mathrm{p}<0.001\right)$, and mean biomass turnover rates $\left(\mathrm{r}^{2}=0.342, \mathrm{p}=0.002\right)$ were significantly correlated with chl a concentration (Table 2). These results indicate that bacterial parameters in the central Yellow Sea in the spring are largely dependent on the resource supply from phytoplankton. Many studies have reported that bacterial biomass and production in freshwater and marine environments are positively correlated with phytoplankton biomass and production (Bird \& Kalff 1984, Cole et al. 1988), although weak correlations were reported in some cases (Ducklow 1999). The general mechanism suggested for the coupling of bacterial growth with phytoplankton is an extracellular release of dissolved organic matter (DOM) from phytoplankton (Mague et al. 1979, Bjørnsen 1988). Billen \& Fontigny (1987) demonstrated a rapid response by bacterioplankton to the release of organic matter by phytoplankton during the spring bloom in Belgian coastal waters. Similar couplings of high bacterial biomass to phytoplankton were reported during the North Atlantic Bloom Experiment (Kirchman et al. 1991, Ducklow et al. 1993). Specifically, during the decline of the bloom, Ducklow et al. (1993) estimated that approximately $2 / 3$ of bacterial production accumulated as biomass and $1 / 3$ was removed by grazers or by other forms of mortality. The enhanced bacterial abundance (Fig. 5, Table 1) in the central Yellow Sea, even under intense grazing activity (Fig. 7), indicates that bursts of bacterial growth in response to increases in primary production result in relatively higher bacterial abundance. In addition to the DOM released by phytoplankton, DOM release mediated by zooplankton, protozoa, and viruses is known to support bacterial growth in aquatic environments (see Nagata 2000). It is also probable that these mechanisms are in effect during the bloom.

Our results on the coupling of bacteria with chl a concentrations (i.e. resources) differ from other conclusions in the coastal water of the Yellow Sea. In the turbid coastal mouth of the Yellow Sea, Cho et al. (1994) reported that bacterial production was not significantly coupled with phytoplankton production because of strong tidal mixing. In the Han River estuary of the Yellow Sea, Hyun et al. (1999) found no significant correlation between bacterial growth and chl $a_{\text {, suggesting }}$ that bacterial production does not rely on a supply of organic carbon from phytoplankton because of an

Table 2. Spearman's rank correlation coefficients $\left(\mathrm{r}^{2}\right)$ between bacterial parameters (production, $\mathrm{BP}$; cell number, $\mathrm{BCN}$; and turnover rates, TR) and chl $a$ and temperature. Pooled: bloom plus non-bloom conditions

\begin{tabular}{|c|c|c|c|}
\hline Parameter & BP & $\mathrm{BCN}$ & TR \\
\hline \multicolumn{4}{|c|}{ Pooled $(n=57)$ : } \\
\hline Chl a & $\begin{array}{c}0.212 \\
(p<0.001)\end{array}$ & $\begin{array}{c}0.155 \\
(p=0.002)\end{array}$ & $\begin{array}{c}0.091 \\
(p=0.022)\end{array}$ \\
\hline Temperature & $\begin{array}{c}-0.019 \\
(p=0.300)\end{array}$ & $\begin{array}{c}-0.009 \\
(p=0.491)\end{array}$ & $\begin{array}{c}-0.011 \\
(p=0.441)\end{array}$ \\
\hline \multicolumn{4}{|c|}{ Bloom condition $(n=25)$ : } \\
\hline Chl a & $\begin{array}{c}0.568 \\
(p<0.001)\end{array}$ & $\begin{array}{c}0.237 \\
(p=0.013)\end{array}$ & $\begin{array}{c}0.342 \\
(p=0.002)\end{array}$ \\
\hline Temperature & $\begin{array}{c}0.004 \\
(p=0.762)\end{array}$ & $\begin{array}{c}-0.033 \\
(p=0.382)\end{array}$ & $\begin{array}{c}0.007 \\
(p=0.701)\end{array}$ \\
\hline
\end{tabular}


allochthonous input of terrestrial organic matter. Similarly, Kirchman et al. (1989) reported insignificant coupling between phytoplankton and bacterial populations in the mixed Rhône River plume, and suggested that this was due to an input of allochthonous carbon, and to changes in growth conditions caused by mixing. Unlike the turbid and eutrophic coastal waters, the central Yellow Sea in spring is characterized by an intrusion of the YSWC (Figs. 2 \& 3), with its oceanic (i.e. unturbid and relatively oligotrophic) properties. The springtime intrusion of the YSWC dilutes the nutrient regime of the central Yellow Sea by a factor of 2, compared to nitrate concentrations in February (KORDI 1998). Finally, the microbiological habitat in the central Yellow Sea differs from that in the eutrophic and turbid coastal areas, and the positively significant correlation between bacterial parameters and chl a (Table 2) implies that resource supply from phytoplankton is one of the major factors stimulating bacterial production during the spring bloom in the central Yellow Sea.

On the other hand, despite the mixture of various water masses with different temperature range, the correlations between water temperature and bacterial variables were not significant (Table 2). Low bacterial biomass and production were observed in the high temperature YSWC (Stns F7, F9 and F11), and high bacterial cell numbers and production were measured at the lower temperature stations (Stns B8 and B10). These results also indicate that temperature alone is not a primary factor limiting bacterial populations during the spring bloom in the central Yellow Sea. Many studies have indicated that rather than temperature alone, the interactive effects of temperature and substrates regulate bacterial properties. For example, during a spring bloom in Newfoundland coastal waters, Pomeroy et al. (1991) found that bacterial respiration increased with increasing temperature and substrate concentration, and they speculated that temperature and substrate interactively affect bacterial populations. Shiah et al. (1999), working between 25 and $27^{\circ} \mathrm{N}$ in the East China Sea, reported that temperature was a determining factor for bacterial production on the inner shelf, which is characterized by low temperatures $\left(<20^{\circ} \mathrm{C}\right)$ and high nitrate concentrations, while resources were more important on the outer shelf, which has high temperatures $\left(>20^{\circ} \mathrm{C}\right)$ and low nitrate concentrations. The results may imply that temperature can be a dominant controlling factor when substrate is not growth limiting for the bacteria. Therefore, the lack of a significant correlation between the bacterial parameter and temperature suggests that bacterial abundance and production in spring were more affected by substrate supply (bottom-up control) than by temperature.
It is well established that the impact of grazing on bacterial abundance is substantial in highly productive regions where bacteria are metabolically active and fast growing (Sanders et al. 1992, Dufour \& Torréton 1996, Ducklow 2000). Although bacterial biomass turnover rates were high in the central Yellow Sea, bacterial carbon biomass in the bloom area accounted for only $2.75 \%$ of chl-C (Table 2). The low BCB:chl-C ratio in the central Yellow Sea was owing to smaller increases in bacterial biomass than in phytoplankton biomass. One of the reasons for the low BCB:chl-C ratio in the bloom area was likely because of the time lag between phytoplankton and bacterial growth, a phenomenon of the early stages of phytoplankton blooms (Billen \& Fontigny 1987, Ducklow et al. 1993). Another implication of the low BCB:chl-C ratio is tight grazing control on the fast-growing bacterial biomass in the bloom area. Sherr et al. (1992) reported that bacterivores preferentially removed dividing cells. Del Giorgio et al. (1996) also found that the proportion of active cells was negatively correlated to the loss rate and initial HNF density, indicating that HNF selectively consumed metabolically active cells. From their estimation that metabolically active bacteria were grazed more than 4 times faster than were inactive bacteria, del Giorgio et al. (1996) hypothesized that low proportions of active bacteria in a natural environment may be the direct result of high grazing pressure on active cells, and not a result of substrate limitation. During a bloom in the Gulf of St. Lawrence, Rivkin et al. (1996) found that bacterial and ciliate abundances were low, but the bacterial growth rate and HNF $(<5 \mu \mathrm{m})$ abundance were high, indicating tight foodweb control between prey and predator (bacteriaHNF-ciliates-zooplankton) during bloom conditions. Our results give several indications that bacterivores tightly control bacterial abundance during the bloom in the central Yellow Sea. First, the high HNF abundance associated with the relatively high bacterial abundance in the central Yellow Sea suggests intense grazing activity on bacteria (Table 1). Second, despite the positive relationship between chl-C and bacterial parameters in the bloom (Table 2), the fact that the correlation between bacterial abundance and chl-C is lower than that between bacterial production and chl-C also implies the substantial removal of bacteria by either bacterivores or viruses. Finally, the results of our time-course experiment (Fig. 7) directly demonstrate that HNF numbers fluctuate with bacterial numbers, as has been shown elsewhere (Fenchel 1982, Kirchman et al. 1991). Overall, the high bacterial production during the spring phytoplankton bloom in the central Yellow Sea is due to high specific growth rates despite low biomass increases. Our results suggest that the high bacterial growth in the central Yellow Sea is 
supported by the substrate, while bacterial biomass levels are kept low due to grazing pressure during the spring bloom.

In the bloom area, it is regarded that energy flow through conventional grazing food chains (i.e. from phytoplankton to zooplankton to fish) or benthic utilization of the phytoplankton might be dominant processes (Nielson \& Richardson 1989, Pomeroy et al. 1991). Our results imply that the grazing impact by bacterivores was also important in regulating bacterial abundance during the bloom. Therefore, more comprehensive ecological studies on major biological groups and bio-limiting elements should be conducted to better understand the food web structure and biogeochemical element cycles and to estimate potential fisheries capacity in both pelagic and benthic habitats during and after the spring bloom in the central Yellow Sea.

Acknowledgements. This research was funded by a grant from the Korean Ministry of Science and Technology (PN $97-$ LO-01-03-A-03). We thank Dr. J. H. Lee for providing the raw T-S data, and Dr. E. J. Yang for enumerating the HNF. Dr. B. C. Cho and 3 anonymous reviewers are acknowledged for their comments which improved the early version of this manuscript.

\section{LITERATURE CITED}

Azam F, Fenchel T, Field JG, Gray JS, Meyer-Reil LA, Thingstad F (1983) The ecological role of water-column microbes in the sea. Mar Ecol Prog Ser 10:257-263

Billen G, Fontigny A (1987) Dynamics of Phaeocysts-dominated spring bloom in Belgian coastal waters. II. Bacterioplankton dynamics. Mar Ecol Prog Ser 37:249-257

Billen G, Servais P, Becquevort S (1990) Dynamics of bacterioplankton in oligotrophic and eutrophic aquatic environments: bottom-up or top-down control? Hydrobiologia 207:37-42

Bird DF, Kalff J (1984) Emperical relationship between bacterial abundance and chlorophyll concentration in fresh and marine waters. Can J Fish Aquat Sci 41:1015-1023

Bjørnsen PK (1988) Phytoplankton exudation of organic matter: Why do healthy cells do it? Limnol Oceanogr 33: 151-154

Caron DA (1983) Technique for enumeration of heterotrophic and phototrophic nanoplankton, using epifluorescence microscopy, and comparison with other procedures. Appl Environ Microbiol 46:491-498

Caron DA, Dam HG, Kremer P, Lessard EJ and 6 others (1995) The contribution of microorganisms to particulate carbon and nitrogen in surface waters of the Sargasso Sea near Bermuda. Deep-Sea Res 42:943-972

Chen C, Beardsley RC, Limeburner R, Kim K (1994) Comparison of winter and summer hydrographic observations in the Yellow and East China Sea and adjacent Kuroshio during 1986. Cont Shelf Res 14:909-929

Cho KD, Hong SY, Kim HJ, Yang YR (1983) Structure of shelf front and distribution of planktons in the eastern part of the Yellow Sea. Bull Korean Fish Soc 16:316-329

Cho BC, Choi JK, Chung CS, Hong GH (1994) Uncoupling of bacteria and phytoplankton during a spring diatom bloom in the mouth of the Yellow Sea. Mar Ecol Prog Ser 115: 181-190

Cho BC, Park MG, Shim JH, Choi DH (2001) Sea-surface temperature and $f$-ratio explain large variability in the bacterial production to primary production in the Yellow Sea. Mar Ecol Prog Ser 216:31-41

Choi JK (1991) The influence of the tidal front on primary productivity and distribution of phytoplankton in the mideastern coast of Yellow Sea. J Oceanol Soc Korea 26: 223-241

Choi JK, Noh JH, Shin KS, Hong KH (1995) The early autumn distribution of chlorophyll-a and primary productivity in the Yellow Sea, 1992. J Intl Soc Yellow Sea Res 1:68-80

Choi JW, Sherr BF, Sherr EB (1999) Dead or alive? A large fraction of ETS-inactive marine bacterioplankton cells, as assessed by reduction of CTC, can become ETS-active with incubation and substrate addition. Aquat Microb Ecol 18:105-115

Cole JJ, Pace ML, Findlay S (1988) Bacterial production in fresh and saltwater ecosystems: a cross-system overview. Mar Ecol Prog Ser 43:1-10

Cushing DH (1989) A difference in structure between ecosystems in strongly stratified waters and in those that are only weakly stratified. J Plankton Res 11:1-13

del Giorgio PA, Gasol J, Vaque D, Mura P, Agusti S, Duarte CM (1996) Bacterioplankton community structure: protist control net production and the propostion of active bacteria in a coastal marine community. Limnol Oceanogr 41: 1169-1179

Ducklow HW (1999) The bacterial component of the oceanic euphotic zone. FEMS Microbiol Ecol 30:1-10

Ducklow HW (2000) Bacterial production and biomass in the oceans. In: Kirchman DL (ed) Microbial ecology of the oceans. Wiley-Liss, New York, p 85-120

Ducklow HW, Carlson CA (1992) Oceanic bacterial production. Adv Microb Ecol 12:113-181

Ducklow HW, Kirchman DL, Quinby HL (1992) Bacterioplankton cell growth and macromolecular synthesis in seawater cultures during the north Atlantic spring phytoplankton bloom, May, 1989. Microb Ecol 24:125-144

Ducklow HW, Kirchman DL, Quinby HL, Carlson CA, Dam HG (1993) Stock and dynamics of bacterioplankton carbon during he spring bloom in the eastern North Atlantic Ocean. Deep-Sea Res 40:245-263

Dufour PH, Torréton JP (1996) Bottom-up and top-down control of bacterioplankton from eutrophic to oligotrophic sites in the tropical northeastern Atlantic Ocean. DeepSea Res 43:1305-1320

Fenchel T (1982) Ecology of heterotrophic microflagellates. IV. Quantitative occurrence and importance as bacterial consumers. Mar Ecol Prog Ser 9:35-42

Floodgate GD, Fogg GE, Jones DA, Lochte K, Turley CM (1981) Microbiological and zooplankton activity at a front in Liverpool bay. Nature 290:133-136

Fuhrman JA, Azam F (1980) Bacterioplankton secondary production estimates for coastal waters of British Columbia, Antarctica, and California. Appl Environ Microbiol 39: 1085-1095

Fuhrman JA, Azam F (1982) Thymidine incorporation as a measure of heterotrophic bacterioplankton production in marine surface waters: evaluation and field results. Mar Biol 66:109-122

Hsueh Y (1988) Recent current observations in the eastern Yellow Sea. J Geophys Res 93:6875-6884

Hyun JH, Choi JK, Chung KH, Yang EJ, Kim MK (1999) Tidally induced changes in bacterial growth and viability 
in the macrotidal Han River estuary, Yellow Sea. Estuar Coast Shelf Sci 48:143-153

Kepner RL Jr, Pratt JR (1994) Use of fluorochromes for direct enumeration of total bacteria in environmental samples: past and present. Microbiol Rev 58:603-615

Kim K, Rho HK, Lee SH (1991) Water masses and circulation around Cheju-Do in summer. J Oceanol Soc Korea 26: 262-277

Kim KH, Hyun JH, Lee JH, Shin KS, Pae SJ, Yoo SJ, Chung CS (2000) Springtime distribution of inorganic nutrients in the Yellow Sea: its relation to water mass. J Korean Soc Oceanogr 5:224-232

Kiørboe T, Kaas H, Kruse B, Mohlenberg F, Tiselius P, Ærtebjerg G (1990) The structure of the pelagic food web in relation to water column structure in the Skagerrak. Mar Ecol Prog Ser 59:19-32

Kirchman DL (1990) Limitation of bacterial growth by dissolved organic matter in the subarctic Pacific. Mar Ecol Prog Ser 62:47-54

Kirchman DL, Yenise S, Van Wambeck F, Bianchi M (1989) Bacterial production in the Rhône River plume: effect of mixing on relationships among microbial assemblages. Mar Ecol Prog Ser 53:267-275

Kirchman DL, Suzuki Y, Garside C, Ducklow HW (1991) High turnover rates of dissolved organic carbon during a spring phytoplankton bloom. Nature 352:612-614

KORDI (Korea Ocean Research and Development Institute) (1998) Study on water circulation and material flux in the Yellow Sea. KORDI, Ansan

Lie HJ (1984) A note on water masses and general circulation in the Yellow Sea (Hwanghae). J Oceanol Soc Korea 19: $187-194$

Lie HJ (1986) Summertime hydrographic features in the southeastern Hwanghae. Prog Oceanogr 17:229-242

Lie HJ (1989) Tidal fronts in the southeastern Hwanghae (Yellow Sea). Cont Shelf Res 9:527-546

Lie HJ, Lee S, Lee JH, Cho CH, Tang Y (1999) Is the YSWC a persistent mean flow? International Symposium on Progress in Coastal Engineering and Oceanography, September 9 to 11, Seoul. Ansan, p 25-43

Lie HJ, Cho CH, Lee JH, Lee S, Tang Y (2000) Seasonal variation of the Cheju warm current in the northern east china sea. J Oceanogr 56:197-211

Mague TH, Friberg E, Hughes DH, Morris I (1979) Extracellular release of carbon by marine phytoplankton: a physiological approach. Limnol Oceanogr 25:262-279

Mann KH, Lazier JRN (1991) Dynamics of marine ecosystems. Blackwell, Boston

MOST (Ministry of Science and Technology) (1998) A study on water circulation and material flux in the Yellow Sea on the material balance and biogeochemical cycles of the Yellow Sea. MOST, Ansan

Nagata T (2000) Production mechanisms of dissolved organic matter. In: Kirchman DL (ed) Microbial ecology of the oceans. Wiley-Liss, New York, p 121-152

Nielson TG, Richardson K (1989) Food chain structure of the North Sea plankton communities: seasonal variations of the role of the microbial loop. Mar Ecol Prog Ser 56:75-87

OHA (1978) Technical reports of hydrographic office of republic of Korea. Publication No. 1101, Office of Hydrographic Affairs, Seoul

Park YH (1986) Water characteristics and movements of the YSWC in summer. Prog Oceanogr 17:243-254

Parsons TR, Maita Y, Lalli CM (1984) A manual of chemical and biological methods for seawater analysis. Pergamon Press, Oxford

Editorial responsibility: Jed Fuhrman (Contributing Editor), Los Angeles, California, USA
Pingree RD, Holligan PM, Mardell GT, Forster GR (1975) Summer phytoplankton blooms and red tides along tidal fronts in the approaches to the English Channel. Nature 258:672-677

Pomeroy LR (1974) The ocean's food web, a changing paradigm. BioScience 24:499-504

Pomeroy LR, Deibel D (1986) Temperature regulation of bacterial activity during the spring bloom in Newfoundland coastal waters. Science 233:359-361

Pomeroy LR, Wiebe WJ, Deibel D, Thompson RJ, Rowe GT, Pakulski JD (1991) Bacterial response to temperature and substrate concentration during the Newfoundland spring bloom. Mar Ecol Prog Ser 75:143-159

Porter KG, Feig YS (1980) The use of DAPI for identifying and counting aquatic microflora. Limnol Oceanogr 25: 943-948

Proctor LM, Fuhrman JA (1992) Viral mortality of marine bacteria and cyanobacteria. Nature 343:60-62

Rassoulzadegan F, Sheldon RW (1986) Predator-prey interaction of nanozooplankton and bacteria in an oligotrophic marine environment. Limnol Oceanogr 31:1010-1021

Rieman B, Bjørnsen PK, Newell S, Fallen R (1987) Calculation of cell production of coastal marine bacteria based on measured incorporation of $\left[{ }^{3} \mathrm{H}\right]$ thymidine. Limnol Oceanogr 32:471-476

Rivkin RB, Legendre L, Deibel D, Tremblay JE and 15 others (1996) Vertical flux of biogenic carbon in the ocean: is there food web control? Science 272:1163-1166

Sanders RW, Caron DA, Berninger UG (1992) Relationships between bacteria and heterotrophic nanoplankton in marine and freshwaters: an inter-ecosystem comparison. Mar Ecol Prog Ser 86:1-14

Seung YH, Chung JH, Park YC (1990) Oceanographic studies related to the tidal front in the Mid-Yellow Sea off Korea: physical aspects. J Kor Soc Oceanogr 25:84-95

Sherr BF, Sherr EB, McDaniel J (1992) Effect of protistan grazing on the frequency of dividing cells in bacterioplankton assemblages. Appl Environ Microbiol 58: 2381-2385

Shiah FK, Ducklow HW (1994) Temperature and substrate regulation of bacterial abundance, production and specific growth rate in Chesapeake Bay, USA. Mar Ecol Prog Ser 103:297-308

Shiah FK, Liu KK, Gong GC (1999) Temperature versus substrate limitation of heterotrophic bacterioplankton production across trophic and temperature gradients in the East China Sea. Aquat Microb Ecol 17:247-254

Shiah FW, Chen TY, Gong GC, Chen CC, Chiang KP, Hung JJ (2001) Differential coupling of bacterial and primary production in mesotrophic and oligotrophic systems of the East China Sea. Aquat Microb Ecol 23:273-282

Smith EM (1998) Coherence of microbial respiration rate and cell-specific bacterial activity in a coastal planktonic community. Aquat Microb Ecol 16:27-35

Suttle CA (1994) The significance of viruses to mortality in aquatic microbial community. Microb Ecol 28:237-243

Sverdrup HU (1953) On conditions for the vernal blooming of phytoplankton. J Cons Cons Perm Int Explor Mer 18: 287-295

Turley CM, Hughes DJ (1992) Effects of storage on direct estimates of bacterial numbers of preserved seawater samples. Deep-Sea Res 39:375-394

White PA, Kalff J, Rasmussen JB, Gasol JM (1991) The effects of temperature and algal biomass on bacterial production and specific growth rate in freshwater and marine habitats. Microb Ecol 21:99-118

Submitted: December 3, 2001; Accepted: January 14, 2003

Proofs received from author(s): April 22, 2003 